\author{
Палійчук Анна Вікторівна \\ кандидат мистецтвознавства, \\ доцент кафедри естрадного співу \\ Київської муніципальної академії \\ естадного та циркового мистецтв \\ ORCID 0000-0001-8607-0648 \\ annapaliychuck244@gmail.com \\ Чавус Лариса Іванівна \\ заслужений працівник культури України, \\ ректор Київської муніципальної академії \\ естадного та циркового мистецтв \\ ORCID 0000-0001-8980-5953 \\ konuschenko65@gmail.com
}

\title{
НОЕМАТИЧНІ РИСИ АВТОРСЬКОÏ МОВИ В. ІВАСЮКА
}

\begin{abstract}
Мета дослідження - дослідити та визначити показники авторської мови В. Івасюка, розкрити стилістичний зміст його пісенного творчого спадку. Методологія дослідження зумовлена поєднанням історичного та біографрічного підходів у річищі культурологічного методу. Інтегративним $є$ феноменолого-семантичний метод, з підсиленням його ноематичного прямування. Усі перелічені підходи діють у комплексному докладанні до феномена творчої особистості В. Івасюка як знакового для домінантних етичних рис національної української свідомості. Наукова новизна дослідження полягає в тому, що вперше здійснена спроба комплексного розкриття феномену авторської мови В. Івасюка у жанрі естрадної пісні та визначено стиль і стилістику пісенної творчості В. Івасюка як ноематичне явище. Висновки. Своєрідність пісенного вокального інтонування на сучасному етапі обумовлена декількома факторами, які сприяють спільності композиційних ідей самих різних авторів: прагнення до звукозображальності; психологічна заглибленість і виразність музичних образів; змістовна ускладненість твору та його структурної основи. В цілому, можна визначити способи і напрямки взаємодії загальної оперної та камернопісенної вокально-декламаційної стилістики, що актуальні для творчої мови В. Івасюка. Пісенна мелодія як художньо-комунікативний феномен має підвищені рефлексивність та семіотичність, психологічну предметність і вагомість. Вона покликана актуалізувати особистісний ліричний аспект музичного образу як досвід людського співчуття, що долає психологічні протиріччя та забезпечує смислову єдність художнього переживання. Пісенна стилістика узагальнює і репрезентує певні психологічні стани, досвід переживання, сприяє укрупненню та упредметненню почуття (сумарної емоції), безпосередньо звертаючись до іманентного «чистого» абсолютного смислу музики. Головною з сукупності провідних рис індивідуального стилю В. Івасюка виступає поглиблений до інтенціональної смислової основи творчості діалогізм, що заслуговує на визначення як ноематичний.
\end{abstract}

Ключові слова: українська музична культура, пісенна естрада, діалог, авторська мова, стиль, В. Івасюк .

Палийчук Анна Викторовна, кандидат искусствоведения, доцент кафедры эстрадного пения Киевской муниципальной академии естадного и циркового искусств; Чавус Лариса Ивановна, заслуженный работник культуры Украины, ректор Киевской муниципальной академии естадного и циркового искусств

Ноэматические характеристики авторского языка В. Ивасюка

Цель исследования - исследовать и определить показатели авторского языка В. Ивасюка, раскрыть стилистический смысл его песенного творческого наследия. Методология исследования обусловлена сочетанием исторического и биографического подходов в русле культурологического метода. Интегративным является френоменолого-семантический метод, с усилением его ноематичного направления. Все перечисленные подходы действуют в комплексном приложении к феномену личности В. Ивасюка как знакового для доминантных этических черт национального украинского сознания. Научная новизна исследования заключается в том, что впервые предпринята попытка комплексного раскрытия феномена авторского языка В. Ивасюка в жанре эстрадной песни и определены стиль и стилистика песенного творчества В. Ивасюка как ноэматическое явление. Выводы. Своеобразие песенного вокального интонирования на современном этапе обусловлена несколькими факторами, которые способствуют общности композиционных идей самых разных авторов: стремление к звукозображательности; психологическая углубленность и выразительность музыкальных образов; содержательная усложненность произведения и его структурной основы. В целом, можно определить способы и направления взаимодействия общей оперной и камерно-песенной вокально-декламационной стилистики, которые актуальны для творческого языка В. Ивасюка. Песенная мелодия как художественно-коммуникативный феномен имеет повышенные рефрлексивность и семиотичнисть, психологическую предметность и весомость. Она призвана актуализировать личностный лирический аспект музыкального образа как опыт человеческого сочувствия, преодолевающего психологические противоречия и обеспечивающего смысловое единство художественного переживания. Песенная стилистика обобщает и представляет определенные психологические состояния, опыт переживания, способствует укрупнению и овеществления чувств (суммарной эмоции), непосредственно обращаясь к имманентно «чистому» абсолютному смыслу музыки. Главной из совокупности основных характеристик индивидуального стиля В. Ивасюка выступает углубленный до интенциональных смысловых основ творчества диалогизм, который заслуживает определения как ноэматический. В. Ивасюк.

Ключевые слова: украинская музыкальная культура, песенная эстрада, диалог, авторский язык, стиль,

(С) Палійчук А. В., 2019

() Чавус Л. І., 2019 
Paliychuk Anna, Candidate of Art, Associate Professor of the Department of Pop Singing of the Kyiv Municipal Academy of Circus and Variety Arts; Chavus Larisa, Honored Worker of Culture of Ukraine, Rector of the Kyiv Municipal Academy of Circus and Variety Arts

\section{Noematic Characteristics of the V. Ivasyuk Author's Language}

The purpose of the article is to investigate and determine the indicators of V. Ivasyuk's author language to reveal the stylistic meaning of his song creative legacy. The methodology is based on a combination of historical and biographical approaches in line with the culturological method. The phenomenological-semantic method is integrative, with the enhancement of its noematic direction. All of these approaches operate in a comprehensive application to the phenomenon of personality of $\mathrm{V}$. Ivasyuk as a sign for the dominant ethical features of the national Ukrainian consciousness. The scientific novelty of the study lies in the fact that the phenomenon of V. Ivasyuk's author's language in the pop song genre is comprehensively revealed for the first time, the author's style and style of the creator's songs are defined as a noematic phenomenon. Conclusions. The originality of the song vocal intonation at the present stage is based on several factors that contribute to the commonality of compositional ideas of various authors: the desire for sound performance; psychological depth and expressiveness of musical images; substantial complexity of the work and its structural basis. In general, it is possible to determine the ways and directions of interaction between the common opera and chamber-song vocal-declamatory stylistics that are relevant to the creative language of V. Ivasyuk. Song melody as an art-communicative phenomenon has increased reflexivity and semiotichnost, psychological objectivity, and weightiness. It is called upon to actualize the personal lyrical aspect of the musical image as an experience of human sympathy, overcoming psychological contradictions, and ensuring the semantic unity of artistic experience. The song style summarizes and represents certain psychological states, experiences, contributes to the enlargement and reification of feelings (total emotion), directly addressing the immanently "pure" absolute meaning of music. The main of the combination of characteristics of the individual style of V. Ivasyuk deepened to the intentional semantic foundations of his works, is dialogism, which can be defined as noematic.

Key words: Ukrainian musical culture, song art, dialogue, author's language, style, V. Ivasyuk.

Актуальність дослідження. Мистецька постать В. Івасюка і стильові ознаки його музичних творів постали стверджуючою частиною у процесі духовного піднесення української культури, що особливо важливого значення набуло в період Незалежності України та, відповідно, заслуговують особливого вивчення і наукового тлумачення. Творчий спадок В. Івасюка $€$ сталою частиною українського естрадно-виконавського репертуару сучасності, постійним предметом вокально-виконавських інтерпретацій, що, у свою чергу, вимагає актуальних наукових рефлексій. Загальний зміст пісенної творчості видатного митця дозволяє визначити інтонаційний тезаурус української музичної мови як загальносуспільного явища, тобто дозволяє відтворити «інтонаційний словник» української музичної культури другої половини XX століття.

Мета дослідження - дослідити та визначити показники авторської мови В. Івасюка, розкрити стилістичний зміст його пісенного творчого спадку.

Методи дослідження зумовлені поєднанням історичного та біографічного підходів у річищі культурологічного методу. Інтегративним $€$ феноменолого-семантичний метод, з підсиленням його ноематичного прямування. Усі перелічені підходи діють у комплексному докладанні до феномена творчої особистості В. Івасюка як знакової для домінантних етичних рис національної української свідомості

Теоретична база дослідження сформована відповідно до зазначених методологічних напрямів, складовими яких $є$ наукові праці, що містять розробку підходів до вивчення українського пісенного мистецтва, національної естрадної творчості, зокрема творчості В. Івасюка (Л. Кадцин, Т. Кириловська, О. Колубаєв, В. Марищак, М. Маслій, Т. Рябуха, М. Фещук) роботи, що дозволяють вивчати феномен музичного мислення та його жанрово-стильові чинники, у тому числі, у сфері вокального мелосу, виокремлювати особистісні чинники творчості видатних мистецьких постатей у хронотопі світової культури (Р. Барт, М. Бахтін, В. Біблер, М. Бубер, Г. Гадамер, Н. Герасимова-Персидська, У. Еко, М. Каган, Ю. Лотман, П. Рікер, Т. Чередниченко, та інші).

Наукова новизна дослідження полягає в тому, що вперше здійснена спроба комплексного розкриття феномену авторської мови В. Івасюка у жанрі естрадної пісні та визначено стиль і стилістику пісенної творчості В. Івасюка як ноематичне явище.

Виклад основного матеріалу. Явище мови - необхідний компонент у довгому ланцюгу «комунікація - спілкування - трансляція смислу - творче самоздійснення» людини, оскільки через мову реалізується центральний соціальний запит: самовисловлюватися, експлікувати зміст власної свідомості. Але мова $€$ й цілком автономним феноменом, здатним до самопородження та самовдосконалення, оскільки вона узагальнює та впорядковує значні історичні обсяги людського досвіду, впливаючи на формування не лише індивідуальної, а й колективно-етнічної свідомості. Дана її онтологічна властивість примушує У. Еко вважати, що не ми говоримо за допомогою мови, а мова говорить за нашою допомогою, тому «потрібно знати межі, всередині яких мова говорить через нас»; адже «в світі знаків семіологію розкриває світ ідеологій, які знайшли своє вираження в уже усталених способах спілкування» $[12,38]$. Ключовий момент у побудові моделі мовної комунікації для У. Еко - введення поняття коду і пояснення його функції щодо наведення порядку (функції зменшення ентропії джерела інформації), що й дозволяє здійснювати комунікацію, адже «код являє собою систему ймовірностей, яка накладається на рівноймовірність вихідної системи, забезпечуючи тим самим можливість комунікації», а інакше передача інформації нездійсненна [12, с. 56]. Мова все більше постає перед нами як форма 
породження, вироблення смислу, що виконується безліччю значень і означень, завдяки кореспондуючих між собою кодів та лексикодів [12, 72].

Чи вистачає зазначених шляхів теоретичного знання для вирішення головних питань, що виникають в галузі проблеми проблеми художньої комунікації, можна засумніватися, особливо якщо залучити герменевтичний (в його єдності з діалогічним) підхід Г. Гадамера [2], який відразу звернений до уявленням про живу зворотну природу людських смислів і основних смислових означень. Однак, треба відзначити, що гадамерівський підхід не набуває спеціальної системності і адресований мові як, перш за все, словневому та позахудожньому явищу (мові та мовленню як загально-соціальному явищу).

Г. Гадамер виходить з проблеми розуміння, розкриваючи феномен людської спільності, того, що досягається в спілкуванні, показуючи таким чином єдність герменевтичного та діалогічного методів [2]. 3 такої позиції він характеризує й явище мови, дуже близько підходячи до тієї посилки, яку У. Еко, по суті, залишив за межами своєї семіологічної системи. За словами Г. Гадамера, «... процес розуміння взагалі являє собою подію мови - навіть тоді, коли йдеться про позамовні феномени або про голоси, що замовкли та заклякли у буквах - подія мови, що здійснюється в тому внутрішньому діалозі душі з самою собою, в якому Платон бачив сутність мислення» [2, 44]. Тому головною метою комунікації, коли вона виступає смисловим людським феноменом, є досягнення спільності в розумінні (що не означає збігу - тотожності суджень, висловлювань, але свідчить про загальний спосіб світорозуміння.

В цілому, узагальнюючи погляди вище представлених авторів, можливо зазначити декілька позицій. По-перше, якщо комунікація виступає системою передачі знання, репрезентує шлях знання, в цьому значенні своєму вона незворотна, послідовно накопичувальна. По-друге, комунікація прагне до раціоналізації, якої часто досягає за допомогою контекстних стимулів - спілкування спрямовано до згоди в переживанні, визначається і збагачується іманентними стимулами. По-третє, комунікація завжди потребує понятійного апарату, структурно-логічної виразності і фріксованості окремих ланок. Спілкування в основі своїй - психологічний процес, що вимагає емоційної включеності, задіяності переживання, потребує співчуття як знаку згоди та наближення, може відбуватися без видимих фрізичних реакцій, прямих фрізичних зіткнень, але завжди означає мовне узгодження, діалог живих інтерпретацій.

Якщо звернутися до явища музичної комунікації як різновиду комунікації художньої, перш за все, необхідно виявити ступінь адекватності і коректності терміну «мовна комунікація» по відношенню до музики. Відразу слід сказати, що музика $є$ комунікативним процесом в тій мірі, в якій вона $є$ спілкуванням (що, ймовірно, поширюється і на інші види мистецтва) і підходити до неї як до комунікації слід з боку спілкування, зіставляючи аспекти комунікації і спілкування в музично-творчому процесі.

Важко вивчати музичну мову поза жанровою стратифікацією музичної творчості, адже остання найбільш близько підводить до соціальної вмотивованості художніх настанов. Тобто, якщо, з одного боку, проблема мови передує проблемі комунікації та розуміння і саме тому є однією з фрундаментальних у вивченні процесу культурної семантики як структурованої єдності засобів та фрорм смислопокладання, то, з іншого боку, мова мистецтва, у тому числі музична, є наслідком розвитку та відокремлення, автономізації потреби колективної людської свідомості у створенні власного смислового середовища, ноематичного середовища, яке, віддзеркалюючи ноосферні епістеми, знаходить необхідні для втілення та зберігання провідних ноем - загальножиттєвих смислів - знакові структури та способи їх трансляції.

Важливим виявляється питання єдності, широти й резонансної сили мовного матеріалу, що суттєво зростає, загострюється в умовах глобалізованого суспільства. Мова - це завжди вибір способу спілкування, але це й екзістенціально значимий вибір каналу самоусвідомлення та самоідентифікації. Тобто мовне вираження людини є нормою її щоденного існування, водночас головним засобом регулювати, вдосконалювати, ціннісно підвищувати це існування, надавати йому понад-буденного значення. 3 цього боку спілкування й розуміння, також інтерпретація, тобто усе коло герменевтичних феноменів, можуть бути залученими до «мовних чинників», ще більше підсилюючи той фракт, що проблема мови відноситься до сфери постійних і постійно затребуваних, оскільки вона існує у живому та дієвому просторі культури, власне є необхідною частиною життєпростору культури.

Відтак можна виділити категорію «мови культури» (або «культурної мови») як таку, що дозволяє, по-перше, виокремити головні напрями й предметні ущільнення людських взаємин (саме заради взаємності як ключової ознаки людського порозуміння); по-друге, відповідає вимогам сучасного представлення людини у найбільш відповідному для неї контексті, тобто дозволяє враховувати взаємоперехід сучасного та позатемпорального в ідеї, образи, статуси людини; по-третє, має достатню міру універсальності, тобто здатна поставати саме мовою культури, достатньо незалежною від випадковостей та коливань, створюваних індивідуальними волюнтаристськими трактуваннями або утисками.

Саме до створення подібної мови прямує у своїй пісенній творчості В. Івасюк - тому він і спирається в основному на інтонаційні запаси й можливості пісенних жанрів, причому долучає та єднає два найбільш типові для усуспільненої свідомості, різновиди: ліричний та танцювальний, що пов'язані з провідними мотивами колективної психології. Це міжособистісне ставлення, з якого найбільш значущим постає стан любові, та спільні святкові дозвільні дії, тобто вільна гра як відображення позитивної динаміки самого життя. 
Спеціальної уваги та обговорення заслуговує і той факт, що у творчості В. Івасюка найтіснішим чином злилися композиторська та виконавська форми, причому обидві постають як авторські у різних їх комунікативних вимірах, а виконавська стає пріоритетною у мовному значенні, оскільки безпосередньо реалізує семантичний потенціал музики. Не зважаючи на те, що дана композиційно-семіотична ознака є типовою для первинної жанрової системи, але у творчості В. Івасюка вона розвивається цілком вторинними стильовими шляхами, що власне зумовлює сукупність провідних рис його індивідуального стилю. Головною з них виступає поглиблений до інтенціональної смислової основи творчості діалогізм, який заслуговує на визначення (значення) ноематичного. При цьому підкреслимо, що В. Івасюк засвоює, перетворює та транслює творчо-пісенним шляхом ті смисли, що притаманні національній колективній свідомості, але існують в ній у прихованому «мовчазному» стані, тому чекають озвучення та висловлення, мистецької експлікації, віддзеркалюються у фольклорних зразках. Але для своєї дієвості та актуалізації вони потребують нового відродження, звернення знову й знову до того, що є основою ціннісного досвіду національної спільноти.

Музично-інтонаційні відкриття В. Івасюка, які зроблені ним у сфері пісенної творчості, виявилися очікуваними, сприйнялися як впізнавані та зрозумілі, тому одразу набули популярності. Але в цьому й зосереджена корінна особливість мислення та стилю композитора: він не йде від вже існуючого популярного музично-поетичного матеріалу, користуючись ним як текстовою основою інтерпретації та розуміння. Навпаки, В. Івасюк керується власною особистісною інтерпретацією музично-поетичного буття пісенності як художньої парадигми національної свідомості, відтворюючи її специфічні мовні риси, узагальнюючи їх неповторним авторським способом, складає нові пісенні тексти, у яких відкриває нові обрії розуміння не лише музичного матеріалу, а й, насамперед, смислів життя.

3 даних смислів, В. Івасюк обирає, як провідні, ліричне почуття міжособистісного любовного залучення - повної почуттєвої довіри іншому (іншим, світу), відтворення сумісної колективної радості переживання життєвої енергії, динаміки буття. Значення музичної мови при цьому полягає в тому, що ноематично відтворені смисли є екзистенційними, глибинно-усвідомленими, вони притаманні особливій музично-мислячій сфері свідомості, тобто мисленню як музиці, тому й потребують музичної універсалізованої фрорми комунікації - спілкування.

Зазначимо ще дві сторони формування єдиного мовного простору культури як сутнісної умови існування й самоздійснення людини, що вплинули на мовне мислення В. Івасюка. Перша з них виявляє пріоритет усного начала, тобто наголошує ті мовні засоби, що звучать, фокусує увагу на тому факті історичної психології культури, що усі мови, перш за все, повинні звучати, відтак існують у певному слуховому мнемонічному вимірі культурної семантики. Тому чим яскравіша форма звучання - слухова сугестивність - мовних форм, тим більший вплив вони отримують, тим скоріше закріплюються й залишаються в семантичному колі культури. Аудіосприйняття є одним з провідних засобів впливу на людську свідомість, найбільш близьким до її смислових центрів каналом проведення та упорядкування інформації.

Інша сторона примушує повертатись до класичних герменевтичних правил, встановлених Г. Гадамером, зокрема, до визнання фундаментальної ролі традиції у формуванні і функціонуванні мови. Як зазначав німецький фрілософр, розуміння $є$ укоріненим у мові в тому ступені, в якому ця остання (мова) є укоріненою у традиції [61]. Отже «корінним» явищем й поняттям виявляється традиція, причому як історичний феномен, тобто як явище історичної тривалості та узагальненості мовного спілкування. 3 боку традиції можна дійти до думки, що найбільш придатною до виконання завдань розуміння та дієвою є така мовна традиція, яка має найбільшу часову протяжність, що не лише не порушила, але й навіть зміцнила її єдність.

3 обох цих сторін на перший план смислової свідомості (семантичної визначеності) культури виходить мова музики - або музична мова, причому зв'язок між цими двома дефініціями також є системно складним і динамічним. Мова музики - специфічний штучний художньо-знаковий винахід, що передбачає окрему не лише технологічну базу, інструментарій, а й змістову предметну галузь, тобто претендує на створення окремої, іншої порівняно зі звичаєвою буденністю, реальності, що відкриває власні незалежні етико-естетичні параметри. Такій мові треба спеціально вчитися і не лише для використання у творчості, а й задля адекватного сприйняття мистецтва. Ї̈̈ провідною тенденцією стає послідовне невпинне ускладнення, що передбачає нарощування письмового потенціалу та існування у системі саме письмових текстів, з відповідною до них спеціальною системою відтворення і трансляції. До даної системи входить, зокрема, й професійна освіта, що має на увазі підготовку фахівців у галузі музичного мистецтва. Відтак, мова музики знаходиться в розпорядженні мистецьких закладів та їх представників, апелює до меморіальної, тобто зафріксованої у визнаних письмових артефактах, пам'яті культури, протистоїть омасовленню, керуючись поглибленням до рефлексивної сфери свідомості і особистості, і культури.

Музична мова виступає онтологічним знаряддям людини, вродженою здібністю до інтонаційного самовираження та смислового взаємообміну - вона є складовою свідомості, що звучить і прагне відчути себе та інші форми усвідомлення. Музична мова є солідарною з якістю «музикальності» як здатності відчувати світ, та з людяністю як потребою співчувати, тому стає невід'ємною частиною спільного людського життя, входить до обов'язкового обрядово-ритуального перебігу, зберігається в усіх 
ритуалізованих канонізованих формах, в усій системі людської звичаєвості. Тому вона фрормується у безпосередній близькості до ужиткових потреб та вимог, віддзеркалює те, що притаманне усім людям, незалежно від їх професійної і навіть етнічної приналежності, виростає над національними мовами, хоча й зберігає зв'язок з ними. Музична мова, по-перше, зберігає міцні взаємини з буденною словесною мовою, навіть коли проводить певний лексичний відбір та поетизує її, по-друге, націлена на звичайні прояви звичайної людини, відтак піднімає звичайність - звичаєвість до рівня загальнозначущої культурологічної категорії, єдиної, що завжди є сучасною в прямому значення цього слова.

У цьому сенсі музичну мову культури можна вважати мовою повсякденного спілкування або культурно-природною, що не має потреби в перекладі та найбільше підтверджує наступне: якщо музика - це універсальна мовна традиція, то це ії семантичне призначення ґрунтується на тому, що вона висловлює те, що не може бути перекладене іншими мовними засобами. Ідея протиставлення мовних свідомостей, як й ідея зближення словесної та музичної мовних форм, виявляється спровокованою розвитком психолінгвістики, різних тенденцій аналітичної психології, пріоритетом психологічної науки у XX столітті, що зберігається й сьогодні, оскільки саме це дозволяє знайти у свідомості людини особливий буттєвий феномен, що визначає всі фрорми й способи людської екзистенції.

Відтак вже в суто теоретичному аспекті виявляється, що сучасна музично-мовна традиція існує як система звичаєвих музично-творчих практик, тобто як мова масово-популярних музичних форм, серед яких можуть бути виокремлені ті авторські жанрово-стильові внески, які укріплюють, підтверджують художньо-семантичні нормативи традиції, тобто є «укоріненими» в ній. Підкреслимо, що академічна професіоналізація в галузі музичної творчості не заважає авторам, зокрема, В. Івасюку, в певних жанрових формах йти від семантики культури - як від смислотворчості життя, тобто зберігати авторитет традиції, що означає збереження певних мовних норм, музично-фразеологічних стереотипів. Саме від останніх залежить впізнаваність музичного висловлення, відповідно ступінь, і широта його розуміння.

Важливість універсального смислового резонансу є головною передумовою творчості у масово-пісенній сфері. Звернення до загальнозрозумілого, загально притаманного і образного матеріалу, до засобів музичної виразовості примушує переключати хід дослідницького аналізу до сфери культурної комунікації, оскільки художня форма не містить якихось технологічних або змістових таємниць, відкриттів, нових семантичних кодів. Але засоби кодування та авторизації художнього змісту, передумови виникнення авторського ідіостилю містяться на межі жанрової системи у її цілому та семантики культури, мовної традиції культури.

Можна сказати, що дана традиція представляє музичні топоси культури, але не як тільки музичні, а навпаки - вони мають музичну фрорму експлікації тому, що презентують важливі для усвідомлення та вербального представлення життєві смислові конотації, дозволяють чуттєво виправдовувати досвід життя, виявляючи його головні екзистенційні магістралі.

Так пісенна музично-мовна традиція представляє музику у служінні культурі, у спільній з культурою, семіотичній дії. Тому вона постає множинною, поліцентричною, еклектичною, інфрормаційнокомунікативно технологічно спрямованою, оскільки розбудовується у напрямку розширення жанрових меж та координат, хоча, саме як мова культурної традиції, головні критерії видобуває у класикоакадемічній жанрово-стильовій традиції музичного мистецтва, музично-творчого процесу. Завдяки цьому музика продовжує претендувати на роль метамови культури й сьогодні, значно піднімаючись над різного роду традиційними мовневими й навіть наочно-образотворчими конвенціями.

Звертаючись до творчої постаті В. Івасюка та розглядаючи її у контексті сучасної музичномовної традиції, зазначимо наступне. В множині проявів сучасної музичної звичаєвої свідомості В. Івасюк обирає шлях, який пов'язаний з кристалізацією україномовної музично-поетичної лексики, тобто національну українську мову він обирає як інтегративну основу всіх художньо-виразових засобів. Це зумовлює опору на фольклорний пісенний матеріал саме в його артикуляційно-агогічному вимірі такому, що впливає на способи звуковидобування та часового утримання звукообразу. Для фрразування в піснях В. Івасюка показовими є широта та плавність, водночас, строга структурованість, темпоральна ясність, недвозначність, одночасно, цілковита образна визначеність та емоційно-оцінна точність, іноді навіть певна плакатніть, що не веде до спрощення образної ідеї, але надає їй нового соціального резонансу.

Саме звучання українського слова є для композитора стильовим топосом, що дозволяє власне авторське ставлення виражати за посередництвом відбору й музично-композиційного розташування словневого матеріалу, перш за все, смислово наголошені слова розміщувати у приспіві, експозиційні та розробкові словесні рядки зосереджувати у куплетах. Взагалі, особливою рисою стилю В. Івасюка, успадкованою від форми саме популярної, фольклорної у головних витоках пісні $є$ рефренність, тобто повторюваність, яка зумовлена спільними композиційними та образно-смисловими завданнями, покликана виділяти та закріплювати головні ідей й художні форми їх реалізації у пісенному творі.

Рефренність як композиційно-семантичний прийом переростає у циклічність як жанровий авторський метод, що дозволяє збирати множинні прояви пісенної свідомості, з її звичаєвими запитами та понадбуденними потребами, до єдиного кола авторської образної системи. Дана система певним чином дублює ту сучасну музично-мовну традицію, яка існує сьогодні в українській культурі та є пока- 
зовою саме для неї. Тому й музика В. Івасюка, що очевидно передбачила майбутнє усуспільненої національної музичної свідомості, сьогодні $є$ високо затребуваною, актуальною, не втрачає своєї художньої змістовності та інтерпретативної значущості.

Висновки. Своєрідність пісенного вокального інтонування на сучасному етапі обумовлена декількома фракторами, які сприяють спільності композиційних ідей самих різних авторів. Перший з них прагнення композиторів до звукозображальності, яка не стає лише ілюстрацією до поетичного змісту, але й перетворює темброве-колористичні можливості вокального та інструментального голосів в їх фактурній єдності в образно значущі. Другий - психологічна заглибленість і виразність музичних образів, яка забезпечується лаконізмом, навіть формульністю інтонаційних прийомів - вони набувають наскрізний характер, тобто сприймаються як монотематічні. Третім фактором інтонування виступає змістовна ускладненість твору і його опорного структурного начала, вокальної мініатюри. Остання перетворюється на «вірш з музикою» або «музичний вірш», що виправдано цілісним устремління музичної поетології, а це веде й до посилення загальної фрілософсько-естетичної концепції творчості, й до насичення ліричної образності драматичною експресією.

В цілому, можна визначити способи і напрямки взаємодії загальної оперної та камернопісенної вокально-декламаційної стилістики, що актуальні для композиторської творчості В. Івасюка. Пісенна мелодія як художньо-комунікативний феномен має підвищені рефлексивність та семіотичність, психологічну предметність і вагомість. Вона покликана актуалізувати особистісний ліричний аспект музичного образу як досвід людського співчуття, що долає психологічні протиріччя та забезпечує смислову єдність художнього переживання. Пісенна стилістика узагальнює і репрезентує певні психологічні стани, досвід переживання, сприяє укрупненню та упредметненню почуття (сумарної емоції), безпосередньо звертаючись до іманентного «чистого» абсолютного смислу музики. Головною з сукупності провідних рис індивідуального стилю В. Івасюка виступає поглиблений до інтенціональної смислової основи творчості діалогізм, що заслуговує на визначення ноематичного. Значення музичної мови видатного митця при цьому полягає в тому, що ноематично відтворені смисли є екзистенційними, глибинно-усвідомленими, вони притаманні особливій музично-мислячій сфері свідомості автора.

\section{תimepamypa}

1. Володимир Івасюк. Життя - як пісня: спогади та есе / упоряд. Парас-ковія Нечаєва. Чернівці: Букрек, 2003. $216 \mathrm{c}$.

2. Гадамер Х.Г. Актуальность прекрасного: Пер.с нем. / Общ. ред. и вступ. ст. Б.Н. Бессонова. Москва: Прогресс, 1991. 368 с.

3. Герасимова-Персидская Н. Авторство как историко-стилевая проблема // Музыкальное произведение: сущность, аспекты анализа. Київ: Музична Україна, 1988. С. 27-33.

4. Каган М. Музыка в мире искусств. Санкт Петербург, 1996. 232 с.

5. Колубаєв О. Л. Галицька популярна пісня в процесі еволюції регіональної традиції естрадномузичного мистецтва: автореф. дис. ...канд. мистецтвознавства: спец. 17.00 .03 - муз. мистецтво Одес. нац. муз. акад. ім. А. В. Нежданової. Одеса, 2014. 20 с.

6. Лотман Ю. Семиосфера, Культура и взрыв. Внутри мыслящих миров: Статьи. Исследования. Заметки (1968-1972). Санкт Петербург: Искусство, 2000. 704 с.

7. Мозговой М. Становлення і тенденції розвитку української естрадної пісні : автореф. дис. ...канд. мистецтвознавства: спец. 17.00.01 - Теорія та історія культури / Київ. нац. ун-т культури і мистецтв. Київ, 2007.20 с.

8. Назайкинский Е. Звуковой мир музыки. Москва: Музыка, 1988. 256 с.

9. Палійчук А. Ноематичні передумови стильового мислення В. Івасюка // Музичне мистецтво і культура: Науковий вісник Одеської національної музичної академії ім. А.В. Нежданової: зб. наук. статей / гол. ред. О.В. Сокол]. Одеса: Астропринт, 2016. Вип. 23. 269-279.

10. Самойленко О. Сучасна музична мова або мова сучасної музики: дві теоретичні парадигми одного художнього явища // LAUDATIO. Ювілейна збірка наукових статей на пошану професора Юрія Ясиновського / Упор. У. Граб, О. Козаренко, Н. Сиротинська. Львів: Видавець Тарас Тетюк, 2014. С. 155-163.

11. Чередниченко Т. Музыка в истории культуры / Курс лекций: 2-е изд., однотомник. Москва: Долгопрудный: Аллегро-Пресс, 1994. 344 с.

12. Эко У. Отсутствующая структура. Введение в семиологию. Санкт Петербург: ТОО ТК «Петрополис», 1998. 432 c.

\section{References}

1. Volodymyr Ivasiuk. Life is like a song: memories and an essay. Paras-koviia Nechaieva (Ed.). (2003). Chernivtsi: Bukrek [in Ukrainian]. [in Ukrainian].

2. Hadamer Kh.H. (1991). The relevance of the beautiful. Per.s nem. B.N. Bessonov (Ed.). Moscow: Prohress

3. Herasymova-Persydskaia N. (1988). Authorship as a historical-style problem. Musical work: essence, aspects of analysis.. Kyiv: Muzychna Ukraina, 1988. pp. 27-33 [in Russian].

4. Kahan M. (1996). Music in the world of arts. St. Petersburg [in Russian].

5. Kolubaiev O. L. (2014). Galitskaya popular song in the process of evolution of the regional tradition of pop music. Extended abstract of candidate's thesis. after A. V. Nezhdanovoi [in Ukrainian].

6. Lotman, Yu. (2000). The Semiosphere, Culture and the Explosion. Inside the Thinking Worlds: Articles. Research. Notes (1968-1972). St. Petersburg: Yskusstvo [in Russian]. 